\title{
VI \\ THE FORCES OF LIFE AND THE CAUSES OF DEATH
}

Xavier Bichat's Recherches physiologiques sur la vie et la mort was published the year that the century turned. This seems fitting, for the work is a superb synthesis of a great many of the important concepts concerning the living body which had evolved during the eighteenth century. In a sense, it sums up the state that medical theory had achieved by them. While studying La vie et la mort, one sees unmistakably that Bichat was an heir to the vitalists, the organicists, and the sensationalists. In it, Bichat examined the living organism with a view to discerning and describing those characteristics which he believed divide it so utterly from the inert one. Here, he argued with enormous conviction on behalf of the separation of the science of life from that of non-living things with which, he believed, it shares virtually no common ground. Here also, he developed his arguments on behalf of subdividing physiological forces and processes into animal and organic categories. Each life was examined in terms of its supposed properties, its consciousness, its ability to learn, its birth, and its death.

Had Bichat not gone to Paris in 1793, it is unlikely that he would have been able to achieve this and hence any other of his major works. Like a great magnet, that city has always drawn France's most ambitious and creative men to itself. Even in the 1790s, the decade of the most intense travail it has ever suffered, it held out to Bichat and to others the possibility of an opportunity to study, to make important contacts, and to achieve professional advancement in general. As we have seen, Bichat obtained all these things from Paris, largely as a consequence of his very lucky adoption by Desault. The vitalist theory was, by then, widely diffused. And the forces of sensibility and contractility, which preoccupied the organicists, had been, as we have seen, the subjects of assiduous examination for about half a century before Bichat tackled them. The sensationalist theory, albeit of at least seventeenth-century origin, was being subjected to particularly intense scrutiny and application, and that largely in Paris at the very time that Bichat worked there. Bichat used this theory and its attendant epistemology as a kind of binding agent to link together all the other elements of his work.

It is unlikely that Bichat ever went to Auteuil. In fact, he probably had little if anything to do personally with many of the politically-minded philosophes whose ideas had been shaped in Madame Helvétius's salon. That made little difference, however, for Condillac's philosophy had become the common property of Parisian scientists and intellectuals. The Société Médicale d'Émulation must have been a particularly important centre for the diffusion of sensationalist ideas. Apart from that, however, all the concepts we have so far examined were widely discussed at the Hôtel-Dieu, as much a part of the institution as the vermin that crept along its walls. There could have been few more intellectually stimulating medical establishments anywhere just at the turn of the century. 


\section{The forces of life and the causes of death}

To dissect La vie et la mort into the elements that compose it is to be brought face to face with notions clearly developed by persons whose work we have been examining. Bichat admitted as much, pointing out that all those persons who had read Aristotle, Buffon, Morgagni, Haller, Bordeu, and others of similar persuasion would see sources of his ideas there. He saw himself, much as we do, as working in a tradition stretching all the way back to Aristotle. It was not his intention to deceive his readers, he wrote (probably quite truthfully), for "those authors are so well known that I thought it useless to note the critical citations exactly." In any case, it is worth remembering that eighteenth-century authors did not tend to be scrupulous about sifting original ideas from borrowed ones. La vie et la mort, in spite of its borrowed elements, is important because of what Bichat did with his predecessors' notions. Analytic methodology notwithstanding, the complete work is greater than the sum of its parts. The success of Bichat's published writings and the considerable reputation he achieved in a short time attest to the fact that his synthesis and application of physiological theory were unique. It is significant that when François Magendie and Claude Bernard were striving to create a deterministic science of physiology, they found it necessary to marshal many of their arguments specifically against those of Bichat, who had denied the possibility of what they were attempting.

Bichat opened La vie et la mort with the simple assertion: "Life consists in the sum of the functions which resist death."'2 The ephemeral mystery of life and of our consciousness has captivated human curiosity since our mind emerged from a kind of animal semiconsciousness of itself. Bichat dealt with a timeless mystery a bit prosaically, perhaps, by contending that to be alive means fundamentally to be an organized material unit battling subversive forces. With good reason, commentators have generally dismissed the definition as a tautology that enlightens little. It has much in common with Stahl's definition of life as "the conversation of an eminently corruptible body, the faculty or force with whose aid the body is sheltered from the act of corruption." 3 Both men perceived the living body as a kind of organic island, besieged without reprieve by ravaging forces that would dissolve its organization and integrity. According to Bichat, "under such circumstances [living bodies] could not long subsist were they not possessed in themselves of a permanent principle of reaction. This principle is that of life; unknown in its nature, it can only be appreciated by its phenomena." This elaboration does little to dispel the fog, serving no purpose for one desiring something tangible and precise. In fact, it can be quite accurately paraphrased to say that living bodies are alive because they possess the principle of life. In the meantime, in addition to combating the external environment, the life principle directs growth and development. In the child, Bichat wrote, the reactive capacity is superior to the action imposed from without, and there is growth; in the adult, there is a balance between action and reaction; in the old man, life languishes until the reaction overtakes and destroys it."

\footnotetext{
1 Xavier Bichat, 'Préface', Recherches physiologiques sur la vie et la mort, Paris, Brosson, Gabon, 1800, pp. i-iv. Hereinafter cited as $\mathbf{L a}$ vie et la mort.

2 Ibid., p. i.

${ }^{3}$ Georg Ernst Stahl, 'Vrai théorie médicale', in Oeuvres médico-philosophiques et pratiques, 6 vols., ed. by Theodore Blondin, Paris, Baillière, 1860, vol. 3, p. 43.

“ Bichat, La vie et la mort, p. i.
} 


\section{Xavier Bichat}

Every child quickly learns that there are endless varieties of life in the world. He perceives without much apparent difficulty that a plant, a fish, and his pet cat are all alive, as he himself is. This is acquired as an intuition long before he can find words to explain it. Indeed, to describe the thread of reality common to life's myriad species, which ties them together as participants in the experience of life, is very difficult. We all acquire at least some sense of a chain of being that runs through nature, uniting the simpler forms of life by imperceptibly gradated degrees to the more complex ones. To define and to understand this complexity was one of Bichat's principal undertakings in $L a$ vie et la mort. It was above all the notion of two distinct lives that allowed him to make sense of living diversity. Accordingly, as we have already had occasion to see, he based much else upon it.

What Bichat called the organic life includes all those functions that are normally internal, passive, and unperceived. It corresponds to the plant life of the ancient Greek triumvirate of plant, animal, and rational souls. Its realm is the same one Helmont had assigned to the great integrative archeus. When Stahl placed all animal activity under the control of a single rational soul, he actually created conceptual difficulties for subsequent theorists. By not distinguishing between conscious and unconscious functions, animism made the chain of being more difficult to comprehend. Thus it was that Sauvages was led to subdivide the soul into faculties, a device that effectively permitted him to revert to a traditional tripartite division. He believed that the functions Bichat later termed organic were partially, but not exclusively, mechanical. Barthez assigned them to a vital principle. With the exception of Stahl, all believed that there are living functions that exist apart from the conscious psychical life. Above all, they all assumed that the willed, rational and conscious activity is linked to a soul, which is, at the same time, a spiritual entity. Like Bichat, then, all assumed that life has levels into which it must be subdivided to be understood.

Bichat nevertheless considered his particular animal-organic classification to be unique, unrelated to his predecessors' classifications in several important ways. Though Grimaud had stated it clearly,Bichat alone took credit for perceiving its implications. "In reflecting upon the [animal-organic] distinction", he remarked, "I soon perceived that it was not only one of those vast and comprehensive views, one of those great and luminous conceptions that frequently occur to the man of genius who studies physiology; but that it might be made the basis of a methodological classification."s In his introductory remarks to the Anatomie générale, he contended that Grimaud's particular approach, albeit obviously helpful, lacked precision: that is to say, Grimaud acknowledged only the sensations and motions among the external functions. He did not hold the brain to be their centre and had neglected the voice. Internal functions had been only partially examined, and no consideration had been given to the special status of the organs of generation. In fact, Grimaud's division was merely a minor point in the larger context of his study of nutrition. What was merely a classificatory convenience for him became a key concept for Bichat, central to his very conception of vital function and vital law. ${ }^{6}$

\footnotetext{
${ }^{3}$ Xavier Bichat, Anatomie générale appliquée à la physiologie et à la médecine, 4 vols., Paris, Brosson, Gabon, 1801, vol. 1, pp. xcix-cxii. Hereinafter cited as Anatomie générale.

- The naturalist Georges Louis Leclerc de Buffon had also written of two lives and of the life proper to
} 


\section{The forces of life and the causes of death}

The organic life is the essential one and therefore universally distributed throughout all living things. It was this fundamental quality that Bichat had in mind when he described the plant as "only the sketch or rather the ground work for the animal . . . for the formation of the latter, it has been necessary to clothe the former with an apparatus of external organs by which it must be connected with external objects." When animal life is fused on to it, our organism "senses, it perceives, it reflects on its sensations, it moves voluntarily in response to their influences and it communicates its desires, fears, pleasures and pains." In an 1822 edition of La vie et la mort, Magendie commented aptly but tersely that this was a "more brilliant than profound view of the subject".

Bichat found that in the animal, one can distinguish between the organs of the two lives in a number of ways. The parts belonging to the animal life are symmetrical, whereas those of the organic one are irregular in form; animal life is harmonious or regular in its activity, while organic life is not; animal life operates only intermittently, but organic life must be constantly active; animal life is modified by habit, whereas organic life is unaffected by it; rationality belongs to the animal life, while passions are connected to the organic life; animal activity commences at birth, and organic activity is present from the moment of conception; animal life alone can be educated. Because animal life cannot exist without organic life, the former leaves the body first at death.

He had at least the outlines of this distinction as early as 1798 , for that year he published in the Mémoires de la Société Médicale d'Emulation a paper concerning the differences in form between the organs of two lives. Whereas a tree has only random branches on an irregular trunk, animal limbs are always symmetrically arranged on an irregularly shaped body. A single organ of the animal life is always placed along or in relation to a median line that divides the body into two halves. Thus it is that two similar eyes receive light impressions, and the tongue is split by a median line. The nerves that transmit sensory impressions from the eyes, ears, and so on to the brain are symmetrical, as are those which go from the brain to the larynx and locomotive organs. The brain itself exists in two apparently identical parts. On the other hand, the digestive organs, liver, spleen, heart, aorta, vena cava, and other vessels are not absolutely regular.

But all the evidence did not quite fit, and Bichat had to do some verbal juggling to salvage what he was convinced was a physiological principle. The apparent regularity of the glands and kidneys, he warned, is merely illusory. One human lung, for example, has two lobes, and the other three. Furthermore, the nerves and vessels supplying the two sides vary considerably in shape and direction. The pancreas, liver, and salivary glands are not quite on the median line, and so on. The reproductive system participates in both lives and is, as one might expect, symmetrical.

each part of the body. This idea belongs to the concept of the chain of being, a belief in the continuity of life, which the biologist attempts to classify into order, genus, and species. The connexion between Buffon and Bichat, was first drawn in A. Arène, 'Essai sur la philosophie de Xavier Bichat', Arch. Anth. Crim., 1911, 26: 32-35.

'Bichat, La vie et la mort, pp. 1-9.

' François Magendie, note to Bichat, La vie et la mort, 4th ed., augmented with notes by F. Magendie, Paris, Bechet, 1822, pp. 6-7. 


\section{Xavier Bichat}

In other instances, Bichat's examples in support of his viewpoint are rather intriguing and in some sense more persuasive. He interpreted the evidence surrounding symmetry, for example, in such a way as to determine that it increases in proportion to a species' location on the chain of being. Man, nature's allegedly most perfect animal, is also its most symmetrical one. The lowly oyster, on the other hand, is irregular and confined to the shell that covers it, preventing it from having any relation with external bodies. Caterpillars and butterflies are symmetrical. When they enter the intermediate or cocoon stage of their existence, however, they collect themselves into irregularly shaped shells and live completely internalized lives. ${ }^{9}$

The somewhat cynical reader may not be surprised at Bichat's claim that the symmetry principle was original to him. I believe, however, that the catalyst for the idea was Bordeu's tissu muqueux, also known in the eighteenth century as cellular tissue. We generally know it today as connective tissue. In the work, Bordeu described a raphé générale, a kind of constriction that divides the body into right and left sides. The diaphragm is divided into muscles that are directed toward the spine and sternum; there is a mediastinum; a division is evident in the trachea, thyroid gland, thyroid cartilage, cricoid, epiglottis, and nostrils; the oesophagus and pharynx are separated posteriorly by a line or crimping together of fibres; the tongue has a median line; the vertebrae and even the intestines are divided into demicanals; the brain, pineal gland, liver, and pancreas are located in the centre of the body and divided into two parts; the mucous tissue itself is constricted at its centre and so divided as to form a pocket on either side of the body. ${ }^{10}$ There is good reason to suppose that whenever Bichat referred critically to Bordeu's work, he was in fact borrowing and developing it somehow. Thus it was that in 1798, he accused Bordeu of making a forced and unnatural application of a worthy principle. If one merely glances at the list of organs offered above by Bordeu, it is clear that he did not limit symmetry to the organs of what Bichat called the animal life. And Bichat had the advantage of the last word.

The symmetry of the organs of the animal life is paralleled, according to Bichat, by harmony of function. Buffon had observed that there is a harmony of action of the eyes and ears. There is a discordance in the voice, he said, if there is a discordance in the two halves of the larynx. From similar considerations, Bichat derived a second "principle of life", which stated that "harmony is the character of external functions while discordance is the attribute of organic functions". We sense confusedly, he wrote, if one eye or ear or nostril is stronger than the other or if one part of the body is affected by paralysis or spasm. A lack of harmony in the hemispheres of the brain will cause the soul to perceive confusedly. He observed that compression of one of the hemispheres by pus or blood is sometimes known to produce confusion in persons and in animals. " Whereas the fact that one is always left- or right-handed seems to contradict the notion of harmony, Bichat put the phenomenon down to habit. Harmony is not important, however, for the organic life. It makes no difference, for example, if

' Xavier Bichat, 'Organes à forme symmétrique', Mémoires de la Société Médicale d'Emulation 1798, 2 : 477-487; and La vie et la mort, pp. 10-19.

${ }^{10}$ Théophile de Bordeu, 'Recherches sur le tissue muqueux ou l'organe cellulaire', in Oeuvres complètes, 2 vols., Paris, Caille et Ravier, 1818, vol. 2, pp. 753-755; also briefly discussed in 'Recherches sur les maladies chroniques', in ibid., vol. 2, pp. 801-802.

"Bichat, La vie et la mort, pp. 20-36. 


\section{The forces of life and the causes of death}

one kidney is more active than the other or if one salivary gland secretes more saliva than the other. Furthermore, the activity of the glandular system, the circulation, or the respiration is constantly varying as much as twofold or threefold under the influence of various causes. ${ }^{12}$

As inharmoniously as the organic functions may occur, however, they must never be interrupted. It is clear that respiration, circulation, exhalation, absorption, nutrition, assimilation, and decomposition must be continuous. The organs of the animal life, on the other hand, are subject to fatigue and must periodically relax. Rest may be the repose of a single fatigued organ or, when the brain is resting, a generalized sleep. ${ }^{13}$ As we have observed, this notion came directly from Grimaud and indirectly from Barthez, who had stated that only organs "necessary to life" enjoy continual excitation by the vital principle. ${ }^{14}$

A particularly interesting part of Bichat's examination of the two lives had to do with the process of learning. Only the animal life can be taught, he wrote. His assumptions were largely sensationalist ones. Like many other men at the time, he believed that habit is of primary importance in permitting one to learn something of some object. An initial impression, Bichat wrote, is merely agreeable or disagreeable. It is confused and inexact until such time as we begin to decompose it into its parts. To illustrate this point, he used the example of a field of flowers, much as Condillac had offered the view of a countryside. Bichat considered this analysis of the components of some larger whole to be an exercise of judgement.

Unfortunately, he went on, there is an inverse relationship between appreciating something and understanding it. "The more we consider an object, the less sensitive we are to its agreeable or disagreeable qualities, but at the same time, the better we may judge its attributes." We become accustomed not only to a beautiful view but also to an irritating foreign body in contact with a mucous membrane. ${ }^{15}$ Though we are aware of a sudden passage from hot to cold surroundings or the other way around, we soon cease to notice the new temperature. Neither the perfumer nor the cook is sensible of the odours surrounding him. This dulling of sensations by habit is not a function of the sensory organs, but rather of the mind itself, which compares each sensation with preceding ones. "The greater the difference between the actual and the past impression, the livelier will be the sentiment. The sensations which affect us the most are those which we have never before experienced." Thus pain and pleasure tend to their own annihilation. The poets' sentiments, it appears, must retreat before physiological processes, for there can be no eternal sorrows. ${ }^{16}$

These words make it clear that Bichat knew Cabanis' ideas well and found them to be persuasive. Some of Bichat's handwritten lecture notes are preserved at the Library

12 Ibid., pp. 36-38.

13 Ibid., pp. 39-46.

14 Paul Joseph Barthez, Nouveaux éléments de la science de l'homme, Montpellier, J. Martel ainé, 1778, pp. 235-244.

${ }^{15}$ Because mucous membranes line organs in contact with the exterior, such as the bladder and the gut, Bichat taught that it was possible that they shared some of the characteristics of the animal life. Hence these organs respond to habit.

${ }_{16}$ Bichat, La vie et la mort, pp. 47-56; compare Étienne Bonnot de Condillac, 'Essai sur l'origine des connaissances humaines', in Oeuvres complètes, 23 vols., Paris, Ch. Houel, 1798, vol. 1, pp. 157-172. 


\section{Xavier Bichat}

of the Paris Medical Faculty, among them twenty-nine pages entitled 'Discours sur l'étude de la physiologie'. They tell us that Bichat taught his students that "all the sciences are divided into the moral and physical sciences", an idea clearly taken from Cabanis. After a note concerning life's division into two categories, he instructed himself, "Speak here of Cabanis", and observed, "Since Locke and Condillac found the source of our ideas in the senses, it is essential to know these senses". ${ }^{17}$ The connexion between some of Bichat's ideas and those of Cabanis or the other ideologues is made abundantly clear in La vie et la mort also.

The question of the role of habit in the intellectual operations interested both Destutt de Tracy and Cabanis, both of whom read papers on the subject before the second class of the Institute in 1798. In the Elements d'idéologie, which appeared the same year as La vie et la mort, Destutt de Tracy argued that habit affects our sensations, motions, memories, desires, and judgements. As we have seen, Cabanis treated the subject again in Rapports du physique et morale de l'homme. ${ }^{18}$ In fact, he accused Bichat of plagiarism in the preface to the book. While discussing the general topic of the science of man, he appended a footnote stating that he had just heard of Bichat's death, and sharply accusing persons who, without scruple, get hold of others' ideas but neglect to indicate their sources. ${ }^{19} \mathrm{His}$ sense of injustice probably stemmed largely from this element of Bichat's work.

In 1803, the Institute awarded a prize to one Maine de Biran for a paper on 'L'influence de l'habitude sur la faculté de penser'. Maine de Biran was sharply criticized subsequently for not having named Bichat in the work. He defended himself by saying that when he began his work in 1799, La vie et la mort had not yet appeared. On seeing Bichat's book later, he was pleased to see the basis of an idea that he had thought to be exclusively his own. ${ }^{20}$ Such confusion about priorities arose largely because certain ideas floating about medical circles were there for anyone who cared to develop them. Destutt de Tracy, Cabanis, Bichat, and Maine de Biran were all in Paris about 1800 , and they all had occasion to hear something about the relationships between sensations, the internal organs, will, habit, and intelligence.

Habit, according to Bichat, belongs only to the animal life, however. Indeed, life would clearly be menaced if visceral organs were thus affected. Its effect on the organic life is minor, therefore, limited to modifying the hungry stomach and the excretory organs. Even in those two cases, however, Bichat claimed that it does so in proportion to the extent to which these particular functions participate in the animal life because of their contact with such foreign substances as food or excrement. ${ }^{21}$

\footnotetext{
${ }^{17}$ These notes by Bichat were reprinted as a 'Discours sur l'étude de la phisiologie', ed. by A. Arène, Arch. Anthr. Crim., 1911, 26: 161-172. The original manuscript in Bichat's almost impossible hand is in the Bibliothèque de l'École de la Médecine, Box 46, no. VIII. It is translated by William Randall Albury as the 'Discourse on the study of physiology', Stud. Hist. Biol., 1977, 1: 97-105.

18 Pierre Jean Georges Cabanis, Rapports du physique et du morale de l'homme, 4th ed., 2 vols., Paris, Bechet, 1924, vol. 1, p. 187.

19 Ibid., p. xiv.

${ }^{20}$ That letter was discovered in this century and reproduced by V. A. Bertrand in ' $X$ avier Bichat et Maine de Biran', Arch. Anthr. Crim., 1911, 26: 434-443. The dispute was also discussed by Arène, op. cit., note 6 above.

${ }^{21}$ Bichat, La vie et la mort, pp. 56-57.
} 


\section{The forces of life and the causes of death}

Because of his internal organs, Bichat's man or animal was very different from Condillac's statue, which possessed only the organs of what he called the animal life. Condillac had described a passion as a dominant desire deriving from the memory of a pleasant sensation that the statute wished to recreate. ${ }^{22}$ Destutt de Tracy and Cabanis had allowed that internal sensations may modify external ones. Bichat, however, set out to demonstrate that the passions - anger, love, joy, sorrow, and so on - originate in the organic life. Without external sensations to put him in contact with the larger life, of course, man would be bereft of all intellectual activity. But without the internal sensations that give rise to the passions, he would presumably lack the qualities that shape the personality and provide life with its colour. The two lives are occasionally at war in the body, with the passions opposing the judgement and intellect of the animal life.

Anger, fear, and joy all variously affect the heart rate and the circulation; respiration is oppressive when one is very sad; certain passions affect the digestive system, causing vomiting or indigestion. That, wrote Bichat, is because these are the sources of the respective passions. Even gestures, he claimed, attest to the connexion between the passions and the organic life. To indicate an expression of joy, love, hatred, or sadness, one gestures toward the heart, the stomach, or the intestines. Popular expressions to the effect that fury circulates in the veins and stirs up the bile, that anger makes the heart leap, and that jealousy distils its passions into the heart, wrote Bichat, owe as much to physiology as to poetry.

It follows, naturally enough, that organic dispositions contribute to the personality. A person with a strong pulmonary apparatus and energetic circulation possesses what has long been labelled a sanguine temperament, which disposes him to anger and to courage. Envy and hate are more pronounced in someone in whom the bilious system dominates. The opposite of the impetuous, sanguine man is the inactive and dull one, in whom the lymphatics are greatly developed. The imagery of the temperaments is, of course, at least as old as Aristotle. If one accepts this viewpoint, it necessarily follows that man is unavoidably assisted or incapacitated by his unique and largely unalterable physiological make-up.

Human passions alter over a lifetime. Childhood, Bichat wrote, is an age of timidity, because organization is feeble. In youth, the pulmonary and vascular systems are more developed, presumably somehow accounting for the qualities of one's personality in those years. Maturity is the age of virility, ambition, envy, and intrigue all somehow having to do with the alleged fact that the activity of the liver and gastric apparatus is pronounced. Although plants possess an organic life, they lack passions, because they have neither sensory apparatus nor appropriate viscera.

Even though they originate in the organic life, the passions frequently affect the animal life. An angry man's muscular force is doubled or even trebled because of an increase in the power of his heart, and hence in the quantity of circulating blood. Indeed, passions produce a thousand involuntary nuances of force, even in voluntary muscles. These effects are the result of sympathies, imperceptible connexions that exist between two remote and apparently unrelated parts of the body. Bichat probably borrowed this notion and even the term from Barthez. Therefore, while it would seem

${ }^{22}$ Condillac, 'Traité des sensations', in Oeuvres complètes, op. cit., note 16 above, vol. 1, pp. 90-95. 


\section{Xavier Bichat}

that the brain ought not to be affected by the liver, stomach, or intestines, there are numerous sympathies between these organs. They must exist also between the viscera and the voluntary muscles themselves.

The intellect and the passions, therefore, coexist in a kind of balance in the body. For example, Bichat wrote, a man who gets bad news when he is before a crowd constrains his normal responses. "It is the brain whose action has surmounted that of the stomach, the liver and so on; it is the animal life which has reclaimed its empire." The happiest man is one in whom the two lives are in equilibrium, so that the cerebral and internal centres exercise an equal control. ${ }^{23}$ This discussion brings to mind the fourth book of Jonathan Swift's Gulliver's travels, in which the hero visits the land of the Houyhnhnms. These animals, much like horses in appearance, lead superbly rational and ordered lives. They achieve their unparalleled comfort and sobriety, however, because they are never deflected by passions or emotions. Their opposites are the vulgar, unpredictable, violent, and emotional Yahoos, who bear an unmistakable physical resemblance to humans. Bichat probably knew nothing of Swift, but in effect he provided a kind of physiological rationale for his fanciful and satirical venture into the realm of the psyche.

Bichat found that he could distinguish between the two lives on the basis of their origin and development as well. The organic life, he wrote, is active from the moment of conception, but animal life does not truly begin until the senses, the brain, the organs of locomotion, and the voice begin to be exercised after birth. Condillac's statue began to develop its mental faculties only when it had two odours, two temperatures, or any other two sensations to compare. In the womb's constant milieu, the foetus has no consciousness of the medium that nourishes it or the heat that penetrates it. Its motions are unconscious and unwilled, deriving from sympathies between internal organs. The very existence of the foetus, Bichat wrote, "is that of a vegetable and its destruction can only be said to be that of a living being and not of an animated one." It followed that wherever there is any question of saving a mother's life or that of her unborn child, the decision is properly made on the mother's behalf.

Bichat must have had Condillac's work near at hand when he wrote the following lines concerning the newborn:

The sensations are at first confused; they transmit only general images; the eye has only the sensation of light; the ear has only that of general sound; the nose only that of smell. As yet, there is nothing distinct in the general affections of the senses; but from habit the strength of the first impression is lessened and particular sensations begin to take place.

So the animal goes on to develop its mental faculties. "The powers of perception, memory and imagination all of which are preceded and occasioned by the sensations increase and extend in proportion as by repeated excitement they are exercised." At first, the cries of young animals are only confused and unformed sounds with no particular character. Children affect the characteristic sounds of their species only after long effort. In a newborn animal, the limbs are constantly in motion, as it attempts to experience more sensations. Only in time does it learn co-ordination of its muscles. ${ }^{24}$ In the 1822 edition of La vie et la mort, Magendie sensibly pointed out, for

${ }^{23}$ Bichat, La vie et la mort, pp. 58-91.

24 Ibid., pp. 134-151. 


\section{The forces of life and the causes of death}

example, that a ewe can distinguish the voice of her lamb in the flock from the very beginning. As any farmer knows well, there is no question of an animal's having to learn to make and to distinguish the sounds of its species. Nor do the motions of the locomotive organs always require any more education than does the heart. A partridge, for example, emerges running from its shell. ${ }^{25}$ Obviously, there are countless similar examples to be had, if one but thinks about the problems for a while.

Bichat divided the education of the external life into three categories: the senses, the brain, and the body. The first division includes the visual arts, music, cooking, perfumery, and so on; the second has to do with poetry and the sciences; the third concerns riding, dancing, and the mechanical arts. They exist in a reciprocal relationship, he wrote, so that while the philosopher is often physically awkward, the dancer is usually not too bright. This provided him with yet another principle, the "fundamental law of the distribution of vital powers". He believed that a "determinate sum of forces or powers have been spread throughout life; this sum must always remain the same whether its distribution is equal or not; the inactivity of one organ necessarily supposes activity in another." To apply oneself to several studies at once is probably to succeed at none of them. Another consequence of the principle is that while hearing and touch are strong in a blind man, the deaf and dumb man has more accurate eyesight. An eagle has piercing sight but an obscure sense of smell, while the opposite is true of the dog. When vital powers are centred in one life, they are relatively inactive in another. When digestion is going on, for example, the powers of life are centred in that system, and the animal becomes sleepy. Bichat clearly would have considered football scholarships inappropriate for a university.

As a consequence of this same law of the distribution of living forces, Bichat said, various organs are perfected at different stages of life. In infancy, the senses are particularly educated, and the nervous system is proportionately greater in relation to the muscular system than later. In youth, memory and imagination become more active, while in adulthood, the faculty of judgement is developed. In view of this, we would do well to apply children to dancing and music, young people to the fine arts, and the adult to logic and mathematics.

Organic life, ineducable and unaffected by habit, is present from the moment of conception. The heart is the first organ to be formed and to begin acting in the foetus. At the beginning of life, the vital powers are concentrated on growth and nutrition. Exhalation, respiration, and digestion begin only after birth. ${ }^{26}$

Bichat did not discuss the possible social consequences of his physiological theory, though other persons would do so. I commented earlier that it seems to follow from the principles of Locke and Condillac that all human beings possess an equal potential at birth. The infinite variability of our species presumably springs from the complex effects of the environment. This was also the viewpoint of such ideologues as Helvétius, Turgot, and Condorcet. Frank Manuel has shown that it was really only during the French Revolution that Frenchmen began to abandon the seductive notion of innate human equality. Cabanis presented papers before the Class of Moral and Political Sciences of the Institute, arguing that man's physical and moral being is

${ }^{25}$ Magendie, op. cit., note 8 above, pp. 204-205.

${ }^{26}$ Bichat, La vie et la mort, pp. 147-177. 


\section{Xavier Bichat}

widely affected by age, sex, climate, and many other such variables. ${ }^{27}$ Now Bichat would have it that the human temperament and moral character are consequences not only of the environment but also of one's spleen, heart, lungs, and gastrointestinal tract. At best, one can hope to modify one's character by training the will and judgement to moderate impulses coming from the passions of the uneducated internal life.

One is also assisted or fettered, according to Bichat, by the limitations of the animal life. We observed earlier that to receive a sound education, one must concentrate upon the activities of the senses, the brain, or the muscles. One cannot be a good musician, philosopher, and athlete. The division of the animal life into three parts was developed in a most interesting way during the Restoration by the Comte de Saint-Simon, whose political and social philosophy was rooted in a notion of human inequality. He first discovered Bichat's work about 1822 and used it to postulate a hypothetical society in which people were to be channelled according to their natural abilities. "Brain men" would become scientists; "sensory men" would be poets, religious leaders, and ethical teachers; "motor men", the intellectually mediocre majority, would be either industrial workers or administrators. ${ }^{28}$

Finally, Bichat showed that the two lives remain distinct from each other even at death. An ageing person dies gradually. Hearing, sight, taste, and touch fade slowly but perceptibly. Imagination, perception, and memory slow. The muscles of locomotion and the voice falter as the brain becomes less and less active. The imagination weakens, so that often an old man can recall events long past while being unaware of the present. While this goes on, the organic life continues unabated. We fear death, Bichat observed, because we fear extinction of our consciousness. This fading of the animal life, therefore, is really an advantage, for one gradually approaches the vegetable state, thereby removing fear of extinction. ${ }^{29}$

The animal-organic division was a device that frequently permitted Bichat to reconcile the apparently conflicting notions and conclusions of such physicians as Haller and the Montpellier vitalists. It provided him with a kind of conceptual framework around which he proceeded to build his arguments on behalf of vital theory and tissue theory. In all the work he did subsequently in physiology and anatomy, he never lost sight of what he saw as a critical natural division.

One of the most important and instructive features of Bichat's work for the medical historian is his theoretical statement on behalf of the rejection of mechanism and the

\footnotetext{
${ }^{27}$ Frank E. Manuel, 'From equality to organicism', J. Hist. Ideas, 1956, 17: 54-69. See also Manuel's The prophets of Paris, Cambridge, Mass., Harvard University Press 1962, pp. 105-148.

${ }^{28} \mathrm{Manuel}$ (1956), op. cit., note 27 above. This provoked a novel approach to Bichat's physiology on the part of John V. Pickstone, 'Bureaucracy, liberalism, and the body in post-revolutionary France: Bichat's physiology and the Paris School of Medicine', Hist. Sci., 1981, 19: 115-142. Striving mightily for a social interpretation of the apparently apolitical Bichat's work, Pickstone argues that Bichat, like Saint-Simon, saw the bodily parts through an imagery of state organization so that his physiology represents a kind of "bureaucratic corporitism" in which the anatomical elements were also functional elements. On pp. 133-134, he gives an organizational chart comparing Bichat's physiology and a model of social organization characteristic of his time, claiming that a "social physiology was a plausible representation of official France during the Directory". He even compares Bichat's tripod of life to the interactions of the Directors, each with their separate executive functions. The "linguistic habits" to which he attributes this convergence of ideas notwithstanding, I find the argument facile, albeit ingenious.

${ }^{29}$ Bichat, La vie et la mort, pp. 178-189.
} 


\section{The forces of life and the causes of death}

support of vital theory. By this time, there were few defenders of traditional mechanism. The eighteenth-century medical world belonged to physicians who did not doubt that living functions are far more mysterious, complex, and elusive than mere clockwork. Bichat offered his readers a concise and articulate theoretical statement in support of a widely assumed position. It can be summed up by saying that the physical sciences are concerned with regular and hence predictable phenomena, whereas the life sciences deal with infinitely variable and constantly altering events and situations. His arguments, in their own terms, were both sensible and compelling, and most contemporary medical men assented to them. Indeed, they were taught in the medical schools well into the nineteenth century.

Bichat wrote as follows concerning the question of predictability and variability in the natural world:

[Vital powers] vary incessantly in their intensity, energy, development; they are constantly passing from the lowest degree of prostration to the highest pitch of exaltation and they assume a thousand modifications under the influence of the most trifling causes. For the animal is influenced by everything around him; he wakes, he sleeps, rests or exercises himself, digests or is hungry, is subject to his own passions, and to the actions of foreign bodies. On the contrary, the physical laws are invariable, always the same and the source of a series of phenomena which are always the same. Attraction is a physical power; it is always in proportion to the mass of brute matter in which it is observed; sensibility is a vital power, but in the same mass of matter, in the same organic part, its quantity is perpetually changing.

With mathematics, he went on, one can calculate the return of a comet or the resistance of fluid passing through an inert canal. But to calculate the force of a muscle with Borelli, the velocity of blood flow with Keill, or the quantity of air in the lungs with Lavoisier is to build a solid house on shifting sand. One never knows vital fluids after a single analysis, because urine, bile, and saliva vary throughout the day, during disease, and with age. "The instability of the vital powers is the quicksand upon which the calculation of all the physicians of the last century has sunk." The major problem with physiology, Bichat contended, is that it was developed only after physics. Had it been cultivated before, men might have made applications from the former to the latter, rather than the other way around. In that case, rivers might have been seen to flow from the tonic action of their banks, crystals to unite from the excitement they exercise upon their reciprocal sensibilities, and planets to move because they mutually irritate one another at great distances. Today, we would consider the application of such language to the phenomena of physics a reversion to a more primitive, even animistic conception of nature. Bichat, however, was not looking backward toward a simpler or more superstitious age, but rather forward to one in which medical studies would attain a new level of theoretical coherence and methodological sophistication.

Most vitalists were prepared to concede some accessory status to physics and chemistry in the study of life. Bichat, however, emphatically denied even that, claiming that those sciences are wholly alien to it:

There are two classes of beings in nature, two classes of property and two classes of science. Beings are organic and inorganic, properties vital and non-vital, sciences physiological or physical .... The vital properties are sensibility and contractility. The non-vital ones are gravity, affinity and elasticity. ${ }^{30}$

In his handwritten lecture notes, he said of Borelli's application of mechanics to the

${ }^{30}$ Bichat, Anatomie générale, pp. 1-2. 


\section{Xavier Bichat}

study of muscular forces that "The calculations are correct, but the principle from which he begins is false because in each instance, the forces in muscles vary." It is a mistake to consider, as did Boerhaave, that arteries, veins, and other canals in the body act as inert tubes that behave in a precise and predictable manner. Although the physiologist must know something of the laws of optics and acoustics, he must never assume that vital laws and living activity are subject to calculation. Mathematics, therefore, is of no use to physiology. "Insist here", he reminded himself, "on the uselessness of mathematics." 31

Bichat imitated Barthez' language on many occasions when he dealt with the subjects of matter, natural law, and the role of the scientist. His views on matter and its properties were unquestionably shaped by what Barthez had written on the subject. Using words almost identical to those of the Montpellier vitalist, Bichat wrote, "Let us pay homage to the immortal Newton; he was the first to find the Creator's secret, namely that of uniting a simplicity of causes to a multiplicity of effects." As we observed earlier, Barthez had set himself apart both from physicians, who enumerated large numbers of causes for physiological phenomena, and from the animists and mechanists, who tried to assign all living activity to a single cause. Somewhat perversely, Bichat turned Barthez' own words about the "simplicity of causes" and "multiplicity of effects" against him, accusing him of the same fault as that of the dualists. ${ }^{32} \mathrm{He}$ described the vital principle as an empty word, "an assumption as void of truth as to suppose one sole acting principle governing all the phenomena of physics. Amongst the latter, some are derived from gravity, others from elasticity, and still others from affinity. So in the living economy, some result from sensibility, others from contractility and so on." Unable to conceive of these properties as components of matter, Barthez had placed them in the vital principle. With some justification, Bichat merely dismissed as a chimera this notion of a substance that is neither soul nor matter.

However we might be inclined to interpret it, Bichat sincerely believed that his own particular analysis of the body as governed by vital forces was superior to those of all his predecessors. Indeed, he was largely correct when he implied that they had frequently confused words with substantially demonstrated causes. The trouble with the archeus, the soul, and the vital principle, he wrote, is that each one in turn was taken to be the common basis of every physiological explanation, a kind of first cause. Certainly Stahl and Barthez, at least, would have denied searching for or naming first causes. Indeed, the charge was a particularly nasty one to aim at Barthez, who saw himself as a staunch Newtonian. And as we observed, neither Helmont nor Barthez

${ }^{31}$ Bichat, op. cit., note 17 above. A somewhat differently slanted interpretation of Bichat's attitude to the mechanical sciences is found in Geoffrey Sutton, 'The physical and chemical path to vitalism: Xavier Bichat's Physiological researches on life and death', Bull. Hist. Med., 1984, 58: 53-71. Largely examining Bichat's experiments on the death of the heart, lungs, and brain, Sutton emphasizes Bichat's preoccupation with the mechanical action of the heart, which sustains the life of the tissues. The centre of the organic or fundamental life and especially of insensible organic contractility, the heart is the centre of mechanical agitation. The activity of the brain, the centre of the animal life, however, is different in its nature. To demonstrate that, Sutton contends, Bichat was working with the new techniques of galvanism. Interesting and perceptive though his emphasis is, however, it does not detract from the insistence of Bichat on the two sciences.

32 These arguments are discussed in Réjane Bernier, 'La notion du principe vitale de Barthez', Archs. Phil., 1975, 35: 423-441; and in Elizabeth Haigh, 'The vital principle of Paul Joseph Barthez: the clash between monism and dualism', Med. Hist., 1977, 21 : 1-14. 


\section{The forces of life and the causes of death}

really treated the archeus or vital principle respectively as sufficient explanation for all living phenomena, but only for the ones Bichat assigned to the organic life. Bichat's objections had really to do largely with their use of words. "Archeus" or "vital principle" sound very much as though they represent causes. Bichat found such theoretical props to be unacceptable, for, tending to seduce people into substituting names for causes, they allow them to believe that they have accounted for those causes, whose nature nevertheless remains unknown. Although one has to suppose that general causes exist, he wrote, the scientist's eye should be directed to observing their results. ${ }^{33} \mathrm{He}$ appears not to have noticed that this was the very thing Barthez had proposed to do.

According to Bichat, physical properties are permanently attached to matter, whereas vital ones are only temporarily imposed upon it. Chaos, he wrote, would be a state in which matter is devoid of all properties. At the creation, God endowed the universe with gravity, elasticity, affinity, and so on. He animated a portion of it by adding the properties of sensibility and contractility to the physical ones. Life, then, is added on to inert matter. This occurs when an object is brought into contact with something alive, thus undergoing a kind of injection of vitality. "In passing from time to time through the living bodies, matter is penetrated at different intervals with the vital properties which are found in combination with the physical ones." While they are present, the vital properties dominate, so that "fettered by vital properties, the physical ones are continually restrained in the phenomena which they tend to produce." Bichat and Barthez here were divided largely on the question of where the sensible and contractile forces are located, the former assigning them to the tissues and the latter to his hypothetical vital principle. In spite of relying so heavily on Barthez' arguments about material properties, Bichat rarely mentioned his work except to dismiss it. On this occasion, he offered merely a patronizing nod in the direction of Montpellier. "Our art is deeply indebted to several physicians of Montpellier for having driven the Boerhaavian theories from the schools and for having embraced the opposite ones of Stahl", he wrote, "but in departing from the false track which they were pursuing, they have chosen in its place such a wild and tortuous path that I doubt much if they will ever find an outlet." ${ }^{34}$

The vital properties, five in all according to Bichat, derive from the forces of sensibility and irritability, which God conferred upon living matter. These properties incorporate the data and speculations accumulated by Haller and by Bordeu. By imposing his versatile notion of the two lives upon their theories and insights, Bichat showed that their differences of opinion concerning the property of sensibility were not substantial. Both men, he said, were correct in their observations and in their basic conclusions. Their disagreement simply stemmed from the fact that they were talking about the properties of two different lives. Bodily parts do possess unequal amounts of sensibility and contractility, as Haller showed. They also owe their myriad automatic functions to another sort of specific sensibility and contractility, as Bordeu pointed out. Bichat's system even managed to resolve the conflict between Haller and Whytt, whose observations often contradicted each other. The point, as he saw it, is "that if

${ }^{33}$ Bichat, La vie et la mort, pp. 92-98.

${ }^{34}$ Bichat, Anatomie générale, pp. v-ix. 


\section{Xavier Bichat}

these divisions had been clear and precise, if the words sensibility, irritability, tonicity, etc., had all been used in the same sense by all, we would find in the writings of Haller, of Lecat, of Whytt, of Haen, of all the Montpellier physicians, etc., few of those disputes which were of no importance to science and tiresome for those who study them." 35

The point, very simply, is that perception and motion exist in each of the two lives. Their character in the animal life differs in many respects, however, from that in the organic life. The following chart outlining the properties of living bodies is taken from La vie et la mort. ${ }^{36}$

$\begin{array}{llll}\begin{array}{ll}\text { Classes } \\ \text { Vital }\end{array} & \begin{array}{l}\text { Genus } \\ \text { 1. Sensibility }\end{array} & \begin{array}{l}\text { Species } \\ \text { 1. Animal } \\ \text { 2. Organic }\end{array} & \text { Varieties } \\ & \text { 2. Contractility } & \begin{array}{l}\text { 1. Animal } \\ \text { 2. Organic }\end{array} & \text { 1. Sensible } \\ \text { Of tissue } & \text { 1. Extensibility } & & \\ & \text { 2. Contractility } & & \end{array}$

The sensibility of the organic life consists in the faculty of receiving an impression in a particular bodily part. It was this vital property that Bordeu treated when he examined glandular functions. It is equivalent to Glisson's perceptio naturalis. In the animal life, however, the impression is referred to the brain, where it becomes conscious. When an animal responds to the abuse of some part of its body with cries of pain, it is demonstrating animal sensibility, the property Haller described in his paper 'On the sensibility of the parts'. Bichat distinguishes the two sensibilities as follows:

The stomach is sensible to the presence of food, the heart to the stimulus of blood, the excretory tube to the contact of the fluid which is peculiar to it; but the term of this sensibility is in the organ itself. In the same way do the eyes, the membranes of the nose and mouth, the skin and all the mucous surfaces at their origin receive an impression from the bodies which are in contact with them, but afterwards they transmit such impressions to the brain which is the general centre of the sensibility of these organs.

The greater the amount of animal sensibility it possesses, the more "perfect" the animal, for this vital property is the source of the sensations, the perceptions, and the pleasure and pain that regulate them.

For the same reasons as Whytt, Bichat found Haller's classification of the bodily parts into sensible and insensible categories to be too rigid. For example, Haller believed ligaments to be insensible to painful stimuli. Bichat found that while they do not respond to acids, alkalis, or cutting, they are pained when twisted, torn, or distended. Though an animal is not conscious of the blood in its arteries, it cries when a foreign fluid is injected, and so on. But Bichat's division of sensibility into two categories was also too rigid. To make sense of the evidence, he had to admit that animal and organic sensibility are the same in their essential categories, with animal sensibility being a kind of maximum of its organic counterpart. Inflammation can increase organic sensibility to a painful level. It becomes, thereby, animal sensibility. On the other hand, habit can reduce animal sensibility to an organic or unconscious

\footnotetext{
${ }^{3 s}$ Bichat, La vie et la mort, p. 133.

36 Ibid.; see also Bichat, Anatomie générale, pp. xi-xiii, Ixxii-lxxix.
} 


\section{The forces of life and the causes of death}

level. Every organ possesses sensibility, Bichat wrote, but there are a thousand degrees of it between that limited to the organ itself and that perceived by the brain. This admission, it would seem, should have detracted from his commitment to the animalorganic division, but we find no evidence that it did so.

Like Bordeu, Bichat attributed each organ's activity to its own particular sensibility. Because of it, the larynx is closed to everything but air, the intestinal lacteals absorb only chyle, and so on. Alteration of the normal level of sensibility is disease. Serous surfaces, for example, bathe for months in fluid they do not imbibe. If their sensibility should be increased by inflammation, however, a new level comes into equilibrium with that fluid, and absorption takes place, producing oedema. ${ }^{37}$

The two contractilities do not shade into each other, as the sensibilities do. Animal contractility is subject to the will. It is located exclusively in the voluntary muscles and functions in conjunction with the soul, the brain, and the nerves. Organic contractility does not depend on a common centre but exists only in the moving organ itself. Both are intimately linked to their corresponding sensibilities. In the animal life, the brain and nerves transmit the signals between sensibility and contractility. Because the vital properties exist in the same structures in the organic life, such transmission is not necessary.

The vital property of organic contractility provided Bichat with some difficulties. He found that he had to subdivide it in order to have it perform all the functions it ought to. Sensible organic contractility, wrote Bichat, controls organs such as the heart, stomach, intestines, and bladder. An insensible organic contractility governs unperceived functions such as those of excretory ducts, secretion, lymphatics, and other small organs where fluids are disseminated in very small quantities. Indeed, the latter vital property is exercised upon mere molecules of matter. The two subdivisions ought nevertheless to be classified together, he believed, because in spite of external appearance, both types pertain only to the internal life and act independently of the will. Indeed, they are connected by indeterminate gradations. Unlike the case with sensibility, however, organic contractility can never be transformed into its animal counterpart. For example, in no case can intestinal movements ever be made subject to the will. ${ }^{38}$ The insensible organic contractility acted much like irritability, which in Bordeu's terms, provokes a gland's sensibility, causing it to secrete its humour. It was also closely related to the motus naturalis, which, according to Glisson, accompanies the perceptio naturalis in the unconscious activities of the body. Clearly, animal contractility is the same as the irritability Haller discovered in the voluntary muscles, while the sensible organic contractility performs the same functions as the vis insita.

In the Anatomie générale, Bichat asked whether sensibility is a necessary component of contractility. The work of Glisson, Bordeu, and other Montpellier physicians treated them as inseparable, whereas Haller had not. His particular system of vital properties, said Bichat, set this dispute at rest, along with many others. As in the case of other arguments surrounding the two properties, his predecessors were all correct. "First, in the animal life", Bichat wrote, "it is clear that contractility is not a necessary consequence of sensibility; thus external objects often act upon us for a long time and yet

${ }^{37}$ Bichat, La vie et la mort, pp. 99-111.

38 Ibid., pp. 112-121. 


\section{Xavier Bichat}

the voluntary muscles are unmoved. On the other hand, in organic life, these two properties are never separated." 39

Bichat described two other properties of living tissue that are not, strictly speaking, vital properties. That is, they do not leave animal tissue at death, but only when it has decomposed. Thus they are, Bichat believed, more like properties of organization. The extensibility and contractility of texture are observed when the skin stretches with tumours, obesity, or pregnancy, when the dura mater and bones of the cranium are extended in hydrocephalus, and when abscesses or haemorrhages occur in the viscera. When such extension ceases after weight loss, childbirth, draining of abscesses, and so on, the contractility immediately sets in. Many persons, he wrote, including Haller and Barthez, had confused it with the phenomena properly belonging to the insensible organic contractility.

The vital properties are not equally distributed throughout the various parts of the body. A voluntary muscle possesses all the varieties of contractility. When it is activated by nerves, it undergoes animal contractility; when it is excited to contract by a chemical or physical agent directly applied to it, it undergoes sensible organic contractility; when fluids enter it to provide nutrition, they provoke a small vibration in each fibre which is the insensible organic contractilty; when the muscle is severed transversely, the parts retract toward their points of insertion because of their contractility of texture. The heart and intestines lack animal contractility. Such organs as tendons, aponeuroses, and bones possess only insensible organic contractility and contractility of texture, and so on. Finally, a physiologist need not have recourse to any forces but those of sensibility, contractility, and tonicity. The use of such terms as the digestive power by Grimaud and the force de situation fixe by Barthez were erroneous and confusing. The persons who used them were merely confusing the properties of life with its results, Bichat contended. ${ }^{40}$

Having considered the subject of gradual death due to ageing, Bichat turned in the second part of La vie et la mort to the study of violent death from injury. He examined, as we saw in the preceding chapter, the consequences of injury to the heart, the lungs, and the brain, claiming that every sudden death begins by interruption of the circulation, the respiration, or brain activity. While the organic life may exist both before and after the animal life, the latter does not persist even for a moment once the former is extinguished. He chose to study those three specific organs because he believed that the two lives interact by way of the relationship among them. Each of them is essential to the other two, "and since they constitute the three centres in which all the secondary phenomena of the two lives are terminated, whenever they cease to act, the phenomena which depend upon them must cease also and general death ensue."

By describing the three organs as centres, Bichat was reviving a theme with a long history. He admitted as much, saying that physiologists have long been acquainted with the importance of a triple focus of life. ${ }^{41}$ To realize just how long, we need only remind ourselves of the tenacious Greek idea of three souls, or pneumata, in which life

\footnotetext{
39 Bichat, Anatomie générale, pp. cv-cvi.

${ }^{40}$ Bichat, La vie et la mort, pp. 121-129.

41 Ibid., pp. 191-196.
} 


\section{The forces of life and the causes of death}

forces were presumed to reside. More recently, Sauvages stated that one of life's essential features is the interaction of the heart and lungs with the soul, which of course, resides in the brain. Bordeu located various centres of sensibility and claimed that the "brain, the heart, and the stomach are ... the triumvirate, the triple support of life ... they are the three principal centres from which consciousness and motion flow and to which they return after having circulated." 42 In all these cases, it was taken as axiomatic that forces are diffused from a central source. The tenacity of that belief in a trinity of sources or foci is possibly the most interesting puzzle of all.

The observations concerning violent death were based, as we have observed, upon a multitude of careful and often intricate experiments. The work demonstrates very well how fundamental the animal-organic division was to Bichat's system. Countless observations and experiments were interpreted in such a way as to make them correspond to the demands that that division imposed. ${ }^{43}$ Bichat's physiological system, which integrated an antimechanist viewpoint, the animal-organic division, and the sensibility and contractility of bodily parts, produced in total a rather satisfying system. Much about life and the body seemed to be explained in La vie et la mort. The book appeared to take account of a very great many themes that ran through the preceding century of work and speculation. In it, Bichat combined the views of Haller, Whytt, Bordeu, Barthez, Grimaud, Buffon, and others. It was compelling material and remarkably persuasive.

Indeed, Bichat's successors found that to take issue with his notions and to set off in a different conceptual and theoretical direction was not always easy. Magendie was one of the first to study and then to dismiss the animal-organic division in print. $\mathrm{He}$ pointed out, sensibly enough when we look back on it, that it tended to separate organs and phenomena that are, in fact, intimately connected. According to Bichat, for example, the muscular apparatus that carries food from the mouth to the oesophagus belongs to the animal life, whereas the rest of the gastrointestinal tract belongs to the organic life. Yet all work to a common end. The division, therefore, must be arbitrary and deceptive. We can only concur with Magendie. Bichat's arguments on behalf of the absolute separation of the laws and principles governing life from those governing non-life, on the other hand, were somewhat more difficult to counter. Living phenomena are, after all, almost infinitely variable, so that the predictability that is so satisfying to physicists, astronomers, and chemists constantly eludes physicians. It remained for the students of the life sciences to show that the variability was not merely arbitrary, as Bichat believed, and above all, that it did not break physical and chemical laws, as he maintained. Magendie's student Bernard accomplished the task decisively, but not until the middle of the nineteenth century.

While La vie et la mort was being composed, Bichat was already involved with an important new work in anatomy. The vital laws were of considerable importance to the tissue theory of bodily structure. Those persons who approved of the tissue work but considered vital theory to be backward were to be disturbed by the union of those two ideas. For Bichat, however, the tissues were of special significance precisely because he saw them as the structures in which vital forces reside and on which they act.

${ }^{42}$ Bordeu, 'Maladies chroniques', op. cit., note 10 above, pp. 829-831.

${ }^{43} \mathrm{~A}$ good analysis of these experiments is Sutton, op. cit., note 31 above. See also Chapter V. 